\title{
Observations on the courtship behavior and nesting in Phyllomedusa venusta (Anura: Phyllomedusidae) from a seasonally dry forest in Colombia
}

\author{
Juan Salvador Mendoza-Roldán \\ Universidad de los Andes, Bogotá, Colombia. E-mail: js.mendoza122@uniandes.edu.co.
}

\begin{abstract}
Observations on the courtship behavior and nesting in Phyllomedusa venusta (Anura: Phyllomedusidae) from a seasonally dry forest in Colombia. I investigated the reproductive behavior of the poorly known leaf frog Phyllomedusa venusta. Courtship, amplexus, and nesting were observed during the rainy season in an ephemeral pool surrounded by forest. Based on the behavior of a single, amplectant pair, it seems likely that physical stimulation may play a role in courtship in this leaf frog that shows little vocalization. A second amplectant pair formed a nest, with leaves surrounding the clutch in a funnel. Both ends of the nest were plugged with empty jelly egg capsules, which also were dispersed throughout the egg mass. A separate spawn was collected, containing 390 viable eggs. By wrapping eggs in leaves, and depositing water in empty egg capsules in the egg mass and jelly plugs, the frogs doubtless protect developing embryos from desiccation, an important adaptation for leaf-nesting among phyllomedusids.
\end{abstract}

Keywords: amplexus, Caribe, clutch size, reproductive behavior, tree frog.

\begin{abstract}
Resumo
Observações sobre o comportamento de corte e a nidificação em Phyllomedusa venusta (Anura: Phyllomedusidae) de uma floresta sazonalmente seca da Colômbia. Eu investiguei o comportamento reprodutivo da perereca pouco conhecida Phyllomedusa venusta. A corte, o amplexo e a nidificação foram observados durante a estação chuvosa em uma poça temporária circundada por floresta. Com base em um único casal em amplexo, parece provável que a estimulação física possa desempenhar um papel na corte desse anuro que vocaliza pouco. Um segundo casal em amplexo construiu um ninho na forma de funil com folhas envolvendo a desova. Ambas as extremidades do ninho foram fechadas com cápsulas de ovos gelatinosas vazias, que também estavam dispersas por toda a massa de ovos. Foi coletada uma desova separada contendo 390 ovos viáveis. Por enrolar os ovos em folhas e depositar água em cápsulas vazias na massa de ovos e nos tampões gelatinosos, esses anuros sem dúvida protegem os embriões em desenvolvimento contra o dessecamento, uma adaptação importante para a nidificação em folhas entre os membros dessa família.
\end{abstract}

Palavras-chave: amplexo, Caribe, comportamento reprodutivo, perereca, tamanho da desova.

Received 14 February 2017

Accepted 18 July 2017

Distributed December 2017 


\section{Introduction}

Amphibian reproductive modes include a diversity of egg-laying strategies. Anurans usually breed in vertical microhabitats, such as phytotelmata (Wells 2007). Frogs of the family Phyllomedusidae (Duellman et al. 2016) have distinctive morphological, behavioral, and reproductive features (Duellman 2001, Faivovich et al. 2010). With few exceptions, phyllomedusine frogs oviposit on vegetation above bodies of water. This nesting behavior poses risks for developing embryos-e.g., exposure to extreme temperatures, water loss through evaporation, and noxious interactions with predators and parasites. Phyllomedusines employ two strategies to protect embryos from desiccation. In one, females fill their bladders with water and use it to hydrate eggs during amplexus; this occurs within the genus Agalychnis, which deposits eggs on the undersides of leaves (Pyburn 1970). In the second strategy, females Phyllomedusa deposit eggless capsules filled with water, thereby providing moisture for the developing clutch (Pyburn 1980); this behavior characterizes all phyllomedusines that use leaves to create a funnel around their egg masses. Ovipositing females typically work from the bottom to the top of the egg mass, folding the edges of the leaf or leaves together with their feet while depositing eggs (Fenolio 1996). Nesting has been described for 10 of 17 species of leaf-folding phyllomedusines (Langone et al. 1985), as follows: Callimedusa tomopterna (Cope, 1868), C. duellmani (Cannatella, 1982); Phasmahyla exilis (Cruz, 1980), P. guttata (Lutz, 1924), P. jandaia (Bokermann and Sazima, 1978); Pithecopus hypochondrialis (Daudin, 1800), P. rohdei (Mertens, 1926); and Phyllomedusa sauvagii Boulenger, 1882, P. iheringii Boulenger, 1885, and P. burmeisteri Boulenger, 1882. Nesting in Phyllomedusa trinitatis Mertens, 1926, was studied by Kenny (1966) and by Downie et al. (2013); the latter authors also commented on the observations reported by Lescure et al. (1995) for nest building in $P$. vaillanti Boulenger, 1882. Nest building also has been described for Phyllomedusa boliviana Boulenger, 1902 (Vaira 2001), P. azureus (Cope, 1862) (Costa et al. 2010), P. bicolor (Boddaert, 1772) (Venâncio and Melo-Sampaio 2010), and Callimedusa ecuatoriana (Cannatella, 1982) (Brito et al. 2014). Barrio-Amorós (2009) described nests of Phyllomedusa neildi BarrioAmorós, 2006, a species endemic to Venezuela and a member of the $P$. tarsius Species Group. Nests of $P$. neildi contain 255-282 eggs and are constructed from one or more folded leaves; the nests are always found hanging directly above water. Nesting behavior, mating success, nestingsite selection, male call, and male-to-male combat have been described for several species (Agar 1909, Langone et al. 1985, Fenolio 1996, Vaira 2001, Abrunhosa and Wogel 2004, Wogel et al. 2005, Downie et al. 2013, Brito et al. 2014). However, little is known about courtship behavior prior to amplexus.

Phyllomedusa venusta Duellman and Trueb, 1967 is a large frog (SVL 86.3-97.7 mm); males are smaller than females (Duellman 2001). This species belongs to the P. tarsius Species Group and occurs in Colombia and Panama (BarrioAmorós 2006).

Though little information on the biology from the species is available, a description of the tadpoles can be found in Lynch (2006). Colombian seasonally dry tropical forests occupy the Caribbean lowlands that extend from the Magdalena Basin toward the Caribbean Sea in the northern part of the country. The study site is located in the "Serranía de San Jacinto, Montes de María," where rain patterns are bimodally distributed; there is a prolonged, 4-5mo dry season that usually extends from January until March. Annual precipitation ranges from 700$2000 \mathrm{~mm}$. A brief rainy period in April and May, during which as much as $130 \mathrm{~mm}$ of rain falls, usually follows the dry season. This is followed by a dry transition called "Veranillo de San Juan" in July and August. The highest annual precipitation occurs between August and November (Oyuela-Caycedo and Bonzani 2014). 


\section{Materials and Methods}

During an herpetological expedition to San Juan Nepomuceno, Bolívar, I visited the study site during the rainy season in August 2015. The year was characterized by an extreme drought, with the first rains occurring in mid-August, when temporary ponds and streams used for amphibian reproduction were filled with water. Observations were at night with visible white light at a small, abandoned artificial water reservoir located in secondary forest $\left(09^{\circ} 55^{\prime} 35.4^{\prime \prime} \mathrm{N}, 7^{\circ} 10^{\prime} 21.3^{\prime \prime} \mathrm{W}\right.$, $200 \mathrm{~m}$ a.s.1.) (Figure 1). Images of the courtship and nesting behavior were captured with a SONY DSC HX-300 digital camera. Video was edited and uploaded to YouTube (https://www.youtube. com/watch?v=R-fwz3T0wa4).

\section{Results}

Trachycephalus typhonius (Linnaeus, 1758) was the dominant hylid tree frog found on the night of 15 August 2015 after a heavy rainfall. It was observed reproducing explosively the two following nights, when calls from this species dominated the entire acoustic space, with no other species having been heard. On the night of 17 August, there were more Phyllomedusa venusta in the reservoir; only one individual had been observed during the $T$. typhonius reproductive peak. On the night of 18 August, 25 individuals were counted either near the reservoir or vocalizing in the adjacent forest. No $T$. typhonius were seen during the observations of $P$. venusta.

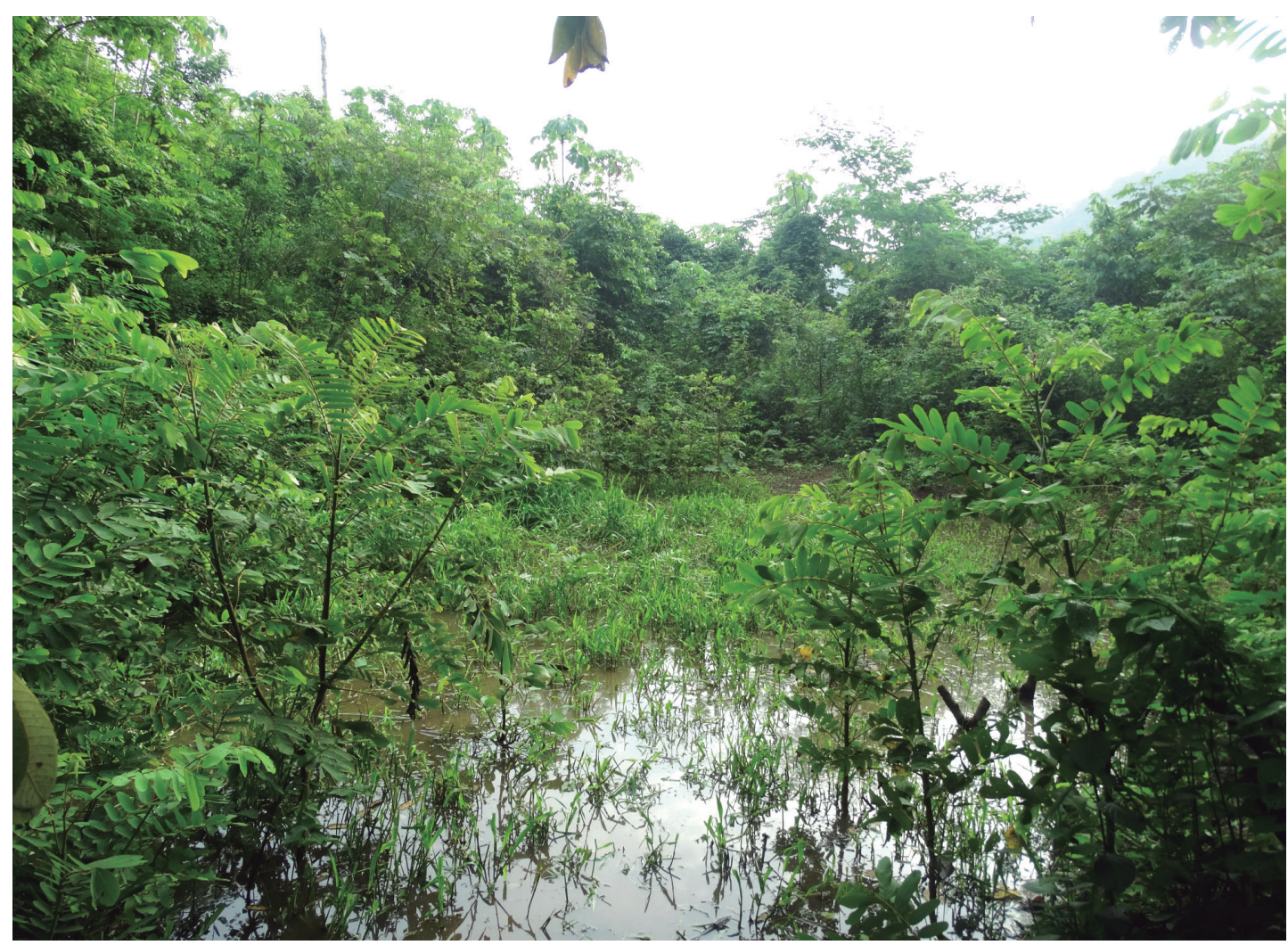

Figure 1. Phyllomedusa venusta breeding site in August 2015, a small temporal pond located inside a second growth forest, Vereda La Pujana, San Juan de Nepomuceno, Bolívar, Colombia. 


\section{Courtship}

Between 17 and 19 August 2015, most Phyllomedusa venusta were vocalizing males. Four females were engaged in amplexus, including the one pair found initiating courtship. Males vocalized from the branches of standing vegetation ranging from $30-200 \mathrm{~cm}$ above the ground. Because this species lacks vocal sacs the vocal repertoire is limited to soft "chuckle" calls Duellman (2001).

Recorded males produce between 9 and 13 chuckle vocalizations in $3 \mathrm{~s}$; as observed on the video in minutes 00:59 and 01:41, these calls consist of a staccato of one repeated note. Males congregate in the vegetation to vocalize, while perched individually on different plants.

At midnight on 18 August 2015, a female was observed on top of a lower branch of the emergent vegetation from the pond moving her back legs. A vocalizing male from the chorus spotted her from a branch a few centimeters away, as seen on the video (minute 02:27). The male first jumped toward the female and embraced her as he landed (minute 02:30). He then adjusted his body position such that he could use his right hand to hold the female, while he rotated his left arm and stroked the side of female's head with his hand. During a period of $7 \mathrm{~s}$, the male stroked the female's head six times, after which the male adjusted his body to initiate amplexus, while the female remained passive (minutes 2:43 to 2:56). The complete course of amplexus is not shown on video because it was observed while the flashlights were turned off; 30 min later, the same female was photographed as she moved with the male on her back to a higher branch of Senna reticulata (Figures 2, 3).

Aggressive behavior between males occurred when solitary individuals attempted to use their hands and feet to press the opponent's eye or gular region; they wrestled with amplectant males attempting to insert their bodies between the pair and fertilize the spawn. As many as four males were observed on top of a single female-a behavior that can last for several hours (Figure 4). A spawn laid after multi-male amplexus seems to be smaller and contain fewer eggs than that of a clutch resulting from a single-malefemale amplexus (Figure 5A).

\section{Nesting}

A second pair of amplectant Phyllomedusa venusta was observed at 22:00 h at night on 19 August. The pair was climbing up the leaves of a tree-Senna reticulata (Willd.) H. S. Irwin and Barneby (Fabaceae). At 03:00 h, the female was observed alone on top of the leaves, having constructed a nest that was $80 \mathrm{~mm}$ long $\times 19 \mathrm{~mm}$ wide, $1.2 \mathrm{~m}$ above the water (Figure 6).On rechecking the nesting site at dawn, I find that the female was gone. The nest contained a clutch of fertile eggs; the top and bottom ends of the nest contained jelly plugs composed of a layer of empty egg capsules and some of these capsules also were dispersed throughout the mass (Figures $5,6)$. On the same night, an adult female (SVL $82 \mathrm{~mm}$ ) was collected and placed in a plastic bag, where she deposited a clutch of 390 viable eggs, mixed with transparent egg capsules. A single, viable egg from this clutch was $2.6 \mathrm{~mm}$ in diameter (Figure 7).

\section{Discussion}

Phyllomedusa venusta is distributed both in dry and humid forest habitats of the Caribbean lowlands and Magdalena River Basin. In dry forests, the species aggregates during reproductive activities. The males vocalize with calls that resemble a "Chack" advertisement call and "Chuckle" aggressive calls typical of phyllomedusines; the latter are generated by the rapid contraction of the body wall (Duellman 2001). Leaf frogs of the genus Phyllomedusa are characterized by limited vocal activity. Some species (e.g., Callimedusa ecuatoriana) have a one-note call composed of two or three pulses (Brito et al. 2014). Vocalizations of P. venusta may be composed of up to 13 repeated chuckles. 

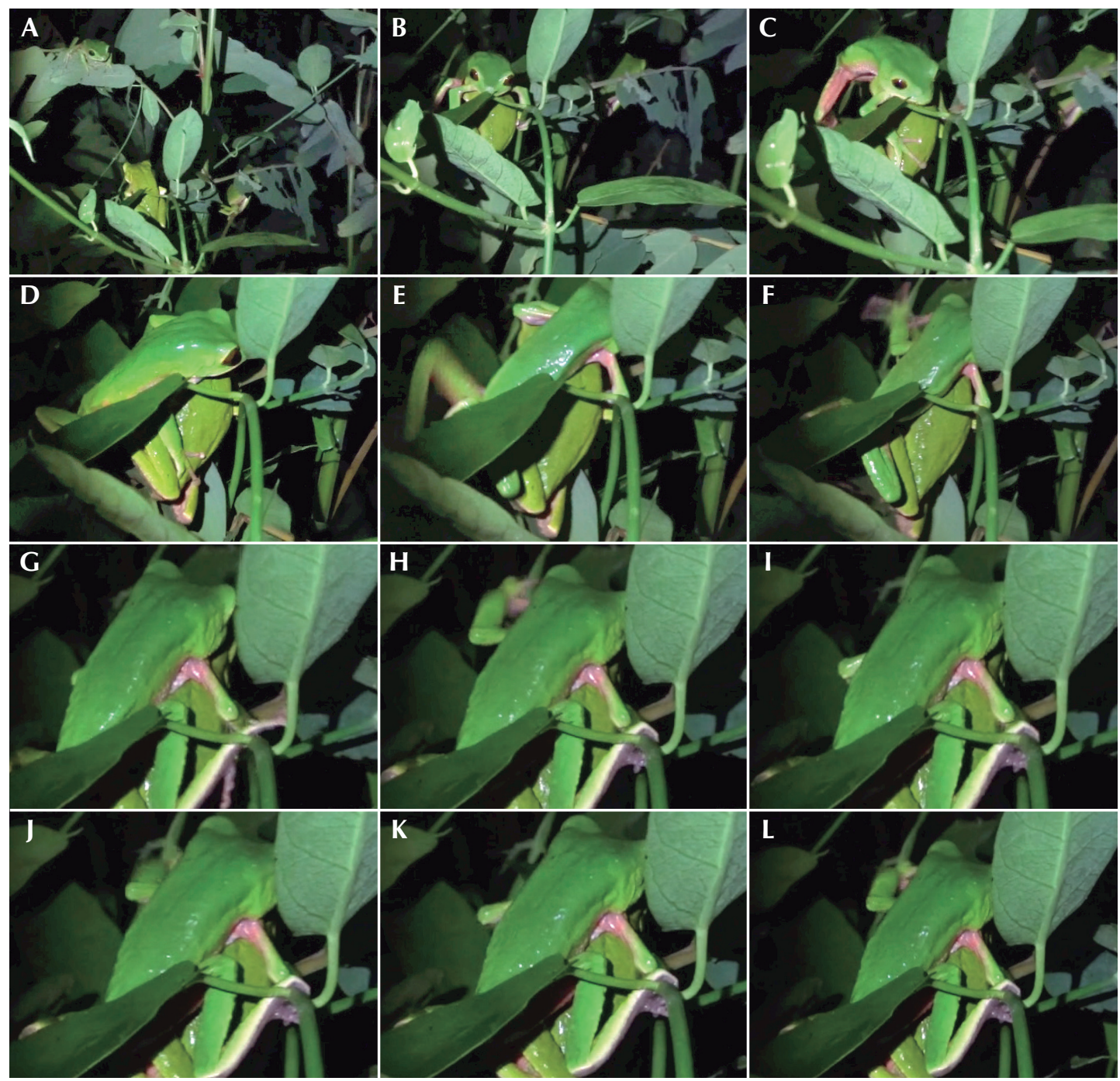

Figure 2. Courtship behavior in Phyllomedusa venusta: (A) Detection of the female; (B) Male reaches female; (C-E) Male re-orientation; (F-L) Physical stimulation of the male over the female's head.

The staccato nature of this low-frequency call causes substantial vibration of the substrate and may play a role in communication that invites for further research. One instance of probable courtship behavior suggests that physical stimulation of the female by the male may play an important role leading to amplexus. The complete sequence involving courtship and oviposition could not be filmed under white light because visible light affects the behavior of this species. The use of night-vision technology might not disturb the frogs during filming.

The clutch of Phyllomedusa venusta collected had more eggs than that of $P$. neildi. Clutch size may be correlated with female body size with $P$. venusta being much larger than $P$. neildi. Nesting 


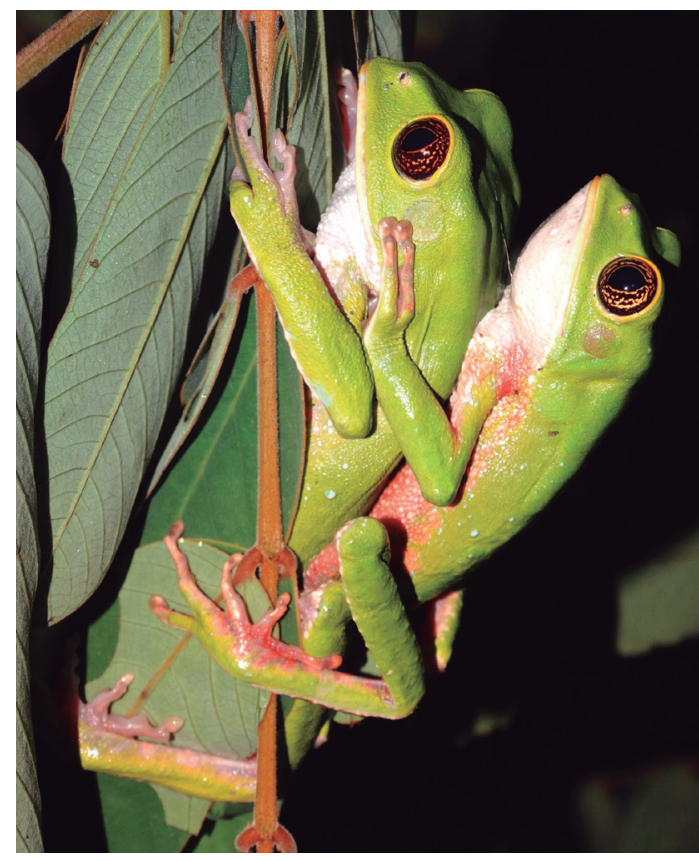

Figure 3. Amplectant pair of Phyllomedusa venusta before egg deposition. in $P$. venusta differs from Fenolio's (1996) description of Pithecopus hypochondrialis (Phyllomedusa auctorum) because Senna leaves close at night and, hang downwards from the branch, the female remains holding the folded leaflets on top of the clutch for the nest to be formed (Figure 6A). This frog makes nests using the main petiole of the compound leaf, sticking leaflets together covering both lateral and frontal aspects of the nest. Nest construction of Phyllomedusa bicolor with non-compound leaves described by Venâncio and Melo-Sampaio (2010) resembles that of $P$. venusta in the use of three leaves; two are lateral covers and one covers the front. In $P$. venusta, leaves on top of the nest are folded over the jelly plug, creating a funnel (Figure 6B). Reproductive adaptations for arboreal nesting shared by these leaf frogs include the presence of top and bottom jelly plugs; these protect against predators and act as barriers to either excessive rain water or desiccation (Downie et al. 2013). Empty egg capsules filled with liquid from the female frog

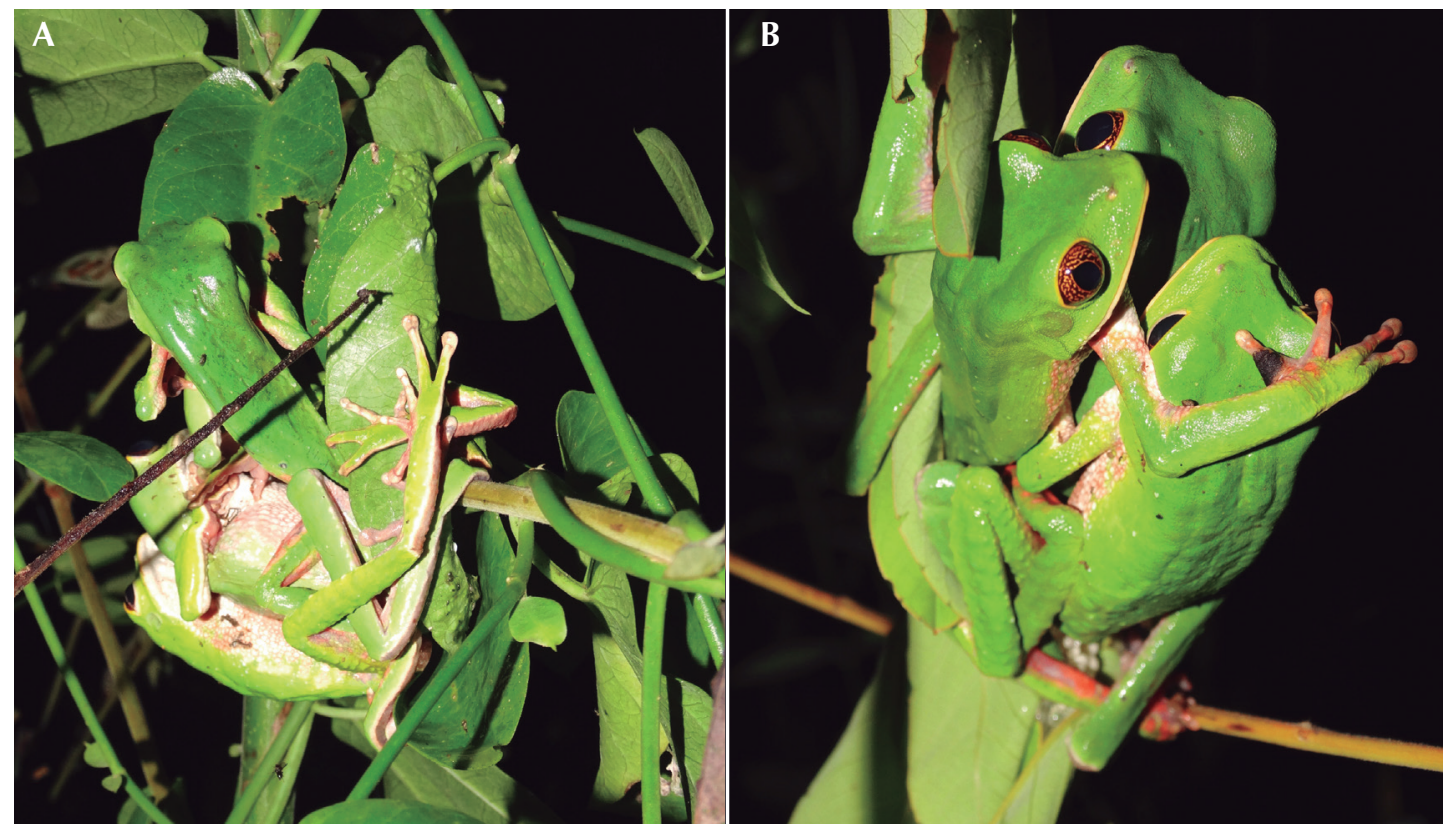

Figure 4. Wrestling males around a female in different reproductive events from Phyllomedusa venusta. 


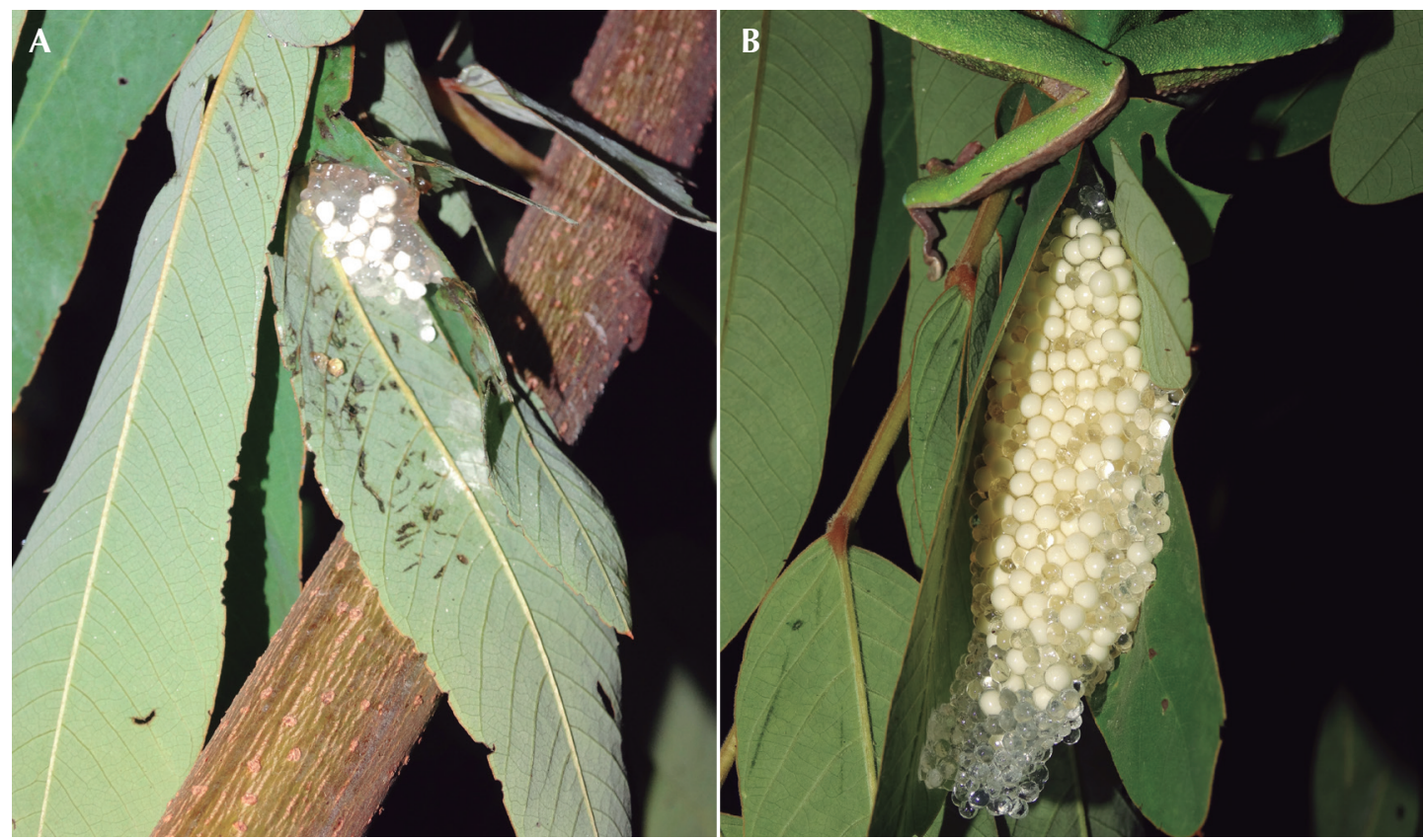

Figure 5. (A) Multi-male spawn in Phyllomedusa venusta. (B) Typical complete nest from normal amplexus in Phyllomedusa venusta.

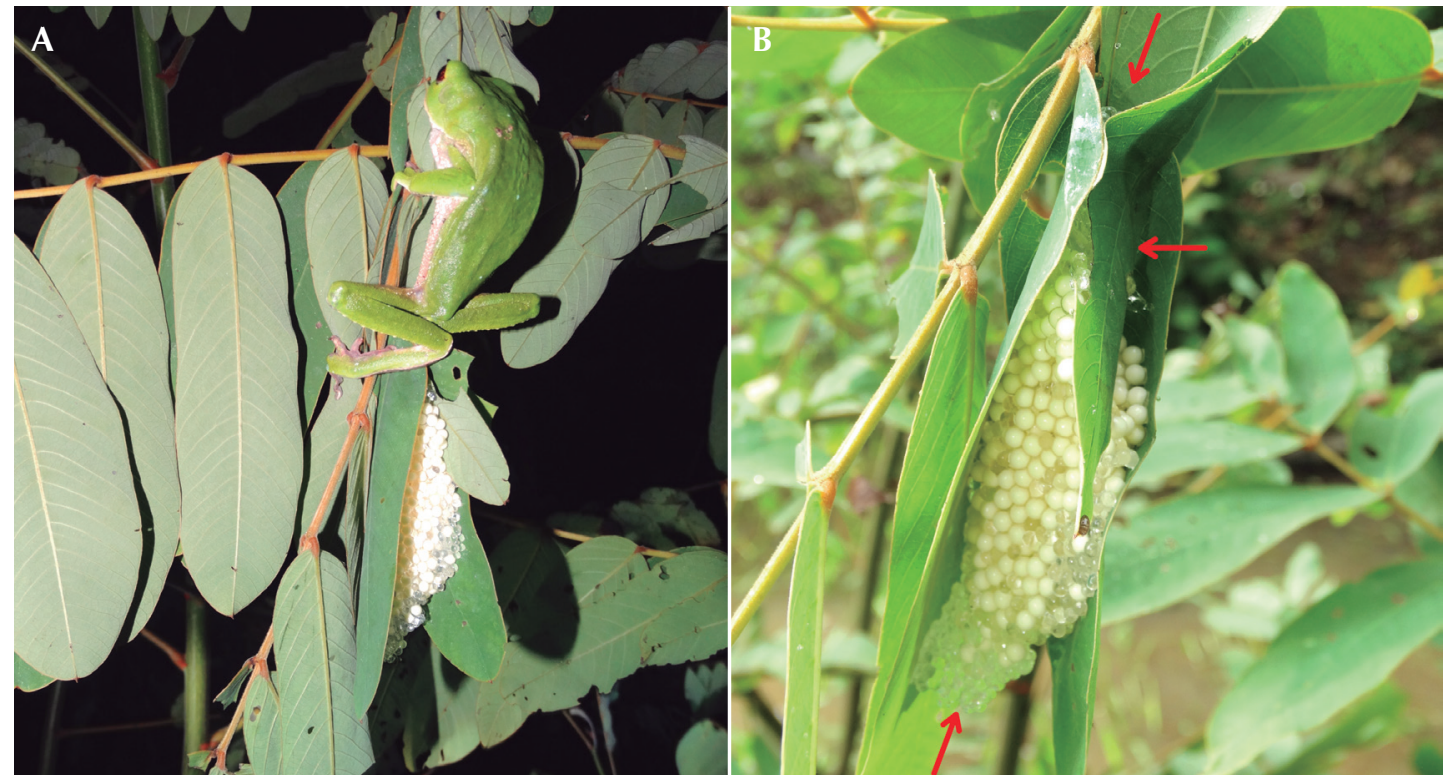

Figure 6. Nest of Phyllomedusa venusta. (A) Female holds leaflets together, to create the top of the funnel. (B) Detail of nest showing the presence of fertile eggs; red arrows indicate the presence of jelly plugs with aggregated capsules on both ends of the nest. 


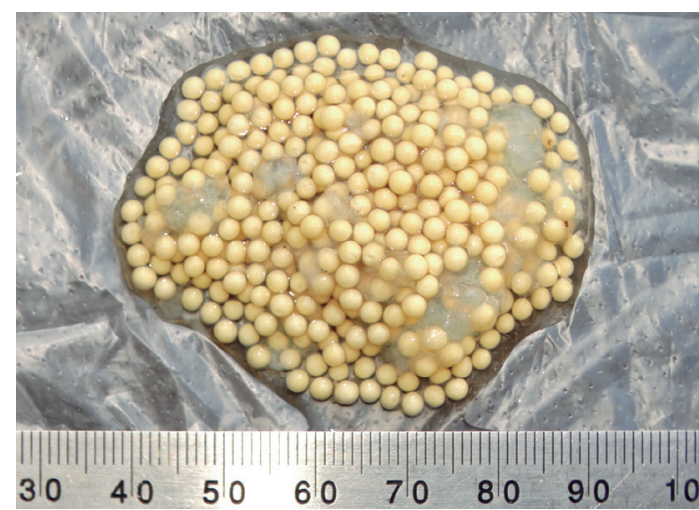

Figure 7. Clutch of Phyllomedusa venusta.

provide moisture for the development of eggs and embryos (Pyburn 1980). The capsules contain other components, such as proteoglycans, lipidic compounds in vacuoles, and hydrophilic proteins; these compounds penetrate the oocytes by intra-oocyte channels, mediating interactions between the environment and the developing larvae (Alcaide et al. 2011). This mechanism may allow the larvae, which are particularly vulnerable to desiccation, to sense environmental cues in habitats with a prolonged dry season and seasonal distribution of precipitation, as in dry forests of the Colombian Caribbean. Studies of the reproductive behavior, ecology, and natural history of this species may aid in appropriate management of the species and its habitat. Further research of the reproductive biology of this leaf frog may yield more new information.

\section{Acknowledgments}

I thank Salvador Vazquez and Noel Torrez and their families for allowing the visits to their farms in vereda La Espantosa and La Pujana at San Juan de Nepomuceno, Bolivar. I am grateful for the comments and important corrections to the manuscript given by Dr. Jaime Bertoluci, Dr. Linda Trueb, two anonymous reviewers, and by Phyllomedusa editorial staff. Also like to give special thanks to Cesar Barrio Amorós for sharing his knowledge on the leaf frogs.

\section{References}

Abrunhosa P. A. and H. Wogel. 2004. Breeding behavior of the leaf-frog Phyllomedusa burmeisteri (Anura, Hylidae). Amphibia-Reptilia 25: 125-135.

Agar, W. E. 1909. The nesting habits of the tree-frog Phyllomedusa sauvagii. Proceedings of the Zoological Society of London 1909: 893-897.

Alcaide, A. P., M. F. Alcaide, F. J. P. Alcaide, and E. O. Lavilla. 2011. The vesicles of Phyllomedusa sauvagii (Anura: Hylidae) nest. South American Journal of Herpetology 6: 20-26.

Barrio-Amorós, C. L. 2006. A new species of Phyllomedusa (Anura: Hylidae: Phyllomedusinae) from northwestern Venezuela. Zootaxa 1309: 55-68.

Barrio-Amorós, C. L. 2009. Distribución y aspectos de la historia natural de las ranas lémur (Hylidae: Phyllomedusinae) en Venezuela. Memoria Fundación La Salle Ciencias Naturales 171: 19-46.

Brito, J., A. Almendáriz, and D. Batallas. 2014. Phyllomedusa ecuatoriana Cannatella (Amphibia: Hylidae): variación, descripción del renacuajo, vocalización y anotaciones sobre la historia natural. Papéis Avulsos de Zoología 54: 419-433.

Costa, T. B., L. D. Guimarães, and R. P. Bastos. 2010. Territorial and mating behavior in Phyllomedusa azurea (Anura: Hylidae) at a temporary pond in west-central Brazil. Phyllomedusa 9: 99-108.

Downie, J. R., M. Nokhbatolfoghahai, D. Bruce, J. M. Smith, N. Orthmann-Brask, and I. MacDonald-Allan. 2013. Nest structure, incubation and hatching in the Trinidadian leaf-frog, Phyllomedusa trinitatis (Anura: Hylidae). Phyllomedusa 12: 13-32.

Duellman, W. E. 2001. The Hylid Frogs of Middle America. Ithaca. Society for the Study of Amphibians and Reptiles. 1159 pp.

Duellman, W. E., A. B. Marion, and S. B. Hedges. 2016. Phylogenetics, classification, and biogeography of the treefrogs (Amphibia: Anura: Arboranae). Zootaxa 4104: 1-109.

Faivovich, J., C. F. B. Haddad, D. Baeta, K. H. Jungfer, G. F. R. Alvares, R. A. Brandão, C. Sheil, L. S. Barrientos, C. L. Barrio-Amorós, C. A. G. Cruz, and W. C. Wheeler. 2010. The phylogenetic relationships of the charismatic poster frogs, Phyllomedusinae (Anura, Hylidae). Cladistics 26: 227-261. 
Fenolio, D. 1996. Captive reproduction of the Orange-legged monkey frog (Phyllomedusa hypochondrialis) and development of a protocol for Phyllomedusine Frog Reproduction in the laboratory. Advances in Herpetoculture, Special Puplications of the International Herpetological Symposium 1: 13-21.

Kenny, J. S. 1966. Nest building in Phyllomedusa trinitatis Mertens. Caribbean Journal of Science 6: 15-22.

Langone, J. A., C. M. Prigioni, and L. Venturino.1985. Informe preliminar sobre el comportamiento reproductor y otros aspectos de la biología de Phyllomedusa iheringi Boulenger, 1885 (Anura: Hylidae). Comunicaciones Zoologicas del Museo de Historia Natural de Montevideo 11: $1-12$.

Lescure, J., Marty, V., Marty, C., Starace, F., Auber-Thomay, M., Letellier, F. (1995): Contribution à l'étude des Amphibiens de Guyane française. X. Les Phyllomedusa (Anura, Hylidae). Revue fr. Aquariol. 2235-50.

Lynch, J. D. 2006. The tadpoles of frogs and toads found in the lowlands of northern Colombia. Revista de la Academia Colombiana de Ciencias 30: 443-457.

Oyuela-Caycedo, A. and R. M. Bonzani. 2014. San Jacinto 1, Ecología histórica, orígenes de la cerámica e inicios de la vida sedentaria en el Caribe colombiano. Barranquilla. Editorial Universidad del Norte. 307 pp.
Pyburn, W. F. 1970. Breeding behavior of the leaf-frogs, Phyllomedusa callidryas and Phyllomedusa dacnicolor in Mexico. Copeia 1970: 209-218.

Pyburn, W. F. 1980. The function of eggless capsules and leaf in nest of the frog Phyllomedusa hypochondrialis (Anura: Hylidae). Proceedings of the Biological Society of Washington 93: 153-167.

Vaira, M. 2001. Breeding biology of the leaf frog, Phyllomedusa boliviana (Anura, Hylidae). AmphibiaReptilia 22: 421-429.

Venâncio, N. M. and P. R. Melo-Sampaio. 2010. Reproductive behavior of the giant leaf frog Phyllomedusa bicolor (Anura: Hylidae) in the western Amazon. Phyllomedusa 9: 63-67.

Wells, K. D. 2007. The Ecology and Behavior of Amphibians. Chicago. University of Chicago Press. 1148 pp.

Wogel, H., P. A. Abrunhosa, and J. P. Pombal. 2005. Breeding behaviour and mating success of Phyllomedusa rohdei (Anura, Hylidae) in south-eastern Brazil. Journal of Natural History 39: 2035-2045.

Editor: Eduardo F. Schaefer 